\title{
COTIDIANO E FACTICIDADE: CONTRIBUIÇÕES PARA UMA GEOGRAFIA DA ESCALA MÍNIMA
}

\author{
DAILY LIFE AND FACTICITY: \\ CONTRIBUTIONS FOR A MINIMUM SCALE GEOGRAPHY
}

\author{
COTIDIANO Y FACTICIDAD: \\ CONTRIBUCIONES A UNA GEOGRAFÍA DE LA ESCALA MÍNIMA
}

\author{
Gilvan Charles Cerqueira de Aráujo ${ }^{1}$ \\ Universidade de São Paulo, São Paulo, Brasil
}

\begin{abstract}
Resumo: Este artigo tem como proposta principal tratar do cotidiano e da facticidade, tendo como aporte teórico e metodológico a análise da escala mínima dos recortes ônticos da realidade objetiva como via de alcance à epifania dos entes. Há dois momentos distintos e complementares que fazem parte deste texto, o primeiro deles apresenta e propõe uma reflexão sobre a facticidade e a ocasionalidade cotidiana, tendo a expressão literária como uma das principais formas de captação destes detalhes da trivialidade fenomênica em sua miríade de recortes fáticos; posteriormente a atenção se volta à escala mínima como metodologia analítica havendo, inclusive, ilustrações aplicativas para este método da diferença ontológica em extensão. Espera-se com estas contribuições que haja um fomento tanto teórico como metodológico ao âmbito dos estudos espaciais (e literários, principalmente) com vistas a esmiuçar o detalhe e nuance escalar das representações fáticas do cotidiano que nos cerca.
\end{abstract}

Palavras-chave: Cotidiano; Facticidade; Escala Mínima; Existência; Ontologia.

Abstract: This article has as main proposal to deal with daily life and facticity, having as a theoretical and methodological contribution the analysis of the minimum scale of the ontic cutting of objective reality as a way of reaching the epiphany of entities. There are two distinct and complementary moments that in to this text, the first one presents and proposes a reflection on facticity and daily life occurrence, with literary expression as one of the main methods of capturing these details of ordinary phenomena in its diffrents factuals cuts; later attention is turned to the minimum scale as analytical methodology and there are also illustrations applying to this method of the ontological difference in spatial extension. These contributions are expected to provide both theoretical and methodological support to the scope of spatial (and literary, primarily) studies with a view to the scalar detail and nuance of the factual representations of everyday life around us.

Keywords: Daily Life; Facticity; Minimum Scale; Existence; Ontology.

\footnotetext{
${ }^{1}$ Pós-doutorando em Geografia pela Universidade de São Paulo, Doutor em Geografia pela Universidade Estadual Paulista, campus de Rio Claro (2016), professor de Geografia da Secretaria de Estado de Educação do Distrito Federal, E-mail: gcca99@ gmail.com
} 
Resumen: Este artículo tiene como propuesta primera tratar de lo cotidiano y de la facticidad, teniendo como sustentación teórica y metodológica al análisis de la escala mínima de los recortes de la realidad objetiva como vía de llegada a la epifanía de los entes. Hay dos momentos distintos y complementarios que forman parte de este texto, el primero de ellos presenta y propone una reflexión en lo tocante a la facticidad y la ocasionalidad cotidiana, teniendo la expresión literaria como una de las principales formas de captación de estos detalles de la trivialidad fenoménica en su diversidad de recortes fácticos; adelante la atención se vuelve a la escala mínima como metodología analítica, incluyendo ilustraciones aplicantes para este método de la diferencia ontológica en la extensión. Se espera con estas contribuciones que haya la promoción tanto teórico como metodológico al alcance de los estudios espaciales (y literarios, en su mayoría) con miras a desmenuzar el detalle y el matiz escalar de las representaciones fácticas de lo cotidiano que nos rodea.

Palabras Clave: Cotidiano; Facticidad; Escala Mínima; Existencia; Ontología.

\begin{abstract}
"Por vezes é nos mais insignificantes e quiméricos exemplos que podemos aprender com mais clareza as lições filosóficas. Sonhar o orvalho como germe e semente é participar do fundo do ser no devir do mundo. Então fica-se certo de viver o serno-mundo, porquanto se é o ser-tornando-se-o-devir-domundo. O alquimista vem ajudar o mundo a devir, vem concluir o mundo. É um operador do devir do mundo. não só colhe o orvalho, mas também o escolhe. Necessita do "orvalho de maio". E esse orvalho de maio, o universo não o entrega ainda suficientemente puro. Então o sonhador paradoxalmente o concentra para exaltá-lo, destila-o e cooba-o para que ele rejeite o que lhe resta de supérfluo, para que se torne germe puro, puramente germinativo, força absoluta." (Gaston Bachelard, A Terra e os Devaneios da Vontade).
\end{abstract}

\title{
1. INTRODUÇÃO
}

A Geografia, como robusto campo de saber nas humanidades, possui um histórico pendular no que diz respeito à base epistêmica e metodológica de suas principais correntes de pensamento. O sujeito e o objeto, a sociedade e a natureza, a geopolítica mundial e as questões regionais e locais, o pertencimento ao lugar e à homogeneização das trocas comerciais globalizantes, dentre outros exemplos. E, apesar desta dualidade escalar, o nível macro, composto pelas meta-teorias sobrepôs-se ao nível singular e cotidiano, talvez por conter em si os grandes discursos e movimentos econômicos que ditam a lógica do espaço global contemporâneo, ou os sistemas políticos erigidos em séculos de hegemonia de pensamento, especialmente no cenário 
ocidental que, muitas vezes, provoca o deslocamento dos indivíduos frente à dialética do mover-se em multidões (NEGRI; HARDT, 2005; SILVEIRA, 2006).

Esta abertura de discussão sobre o descenso e os óbices encontrados das metateorias apresentada como elemento introdutório, demandaria toda uma reflexão de maior porte, que não se configura como objetivo primeiro da discussão proposta neste artigo. Por ora, recomenda-se, sobre esta temática, uma ida a autores que transitaram por entre estes dois extremos, especialmente àqueles que se voltaram para uma dialogia com dimensões do Materialismo Histórico e Dialético de um lado e a Fenomenologia Existencial de outro, como amostra do pêndulo escalar efetuado pelas correntes de pensamento que pautam as análises em diferentes campos do saber, como Jean-Paul Sartre (2010), Karel Kosik (1976), Herbert Marcuse (1968), Carlos Astrada (1942) e Tran-Duc Thao (1959).

Houve trabalhos, no caso da Geografia, que procuraram expandir esta lógica da grande amplitude escalar. Podemos destacar contribuições de Élisée Reclus (2010) em seus textos Do sentimento da natureza nas sociedades modernas (originalmente publicado em 1866) e ensaios sobre a montanha e o arroio (ANDRADE, 1985); a obra O Homem e a Terra de Éric Dardel [1952] (2011); autores anglo-saxões representantes da via cultural na Geografia, além da releitura das aproximações da crítica marxista com os temas culturais efetuados pelos pensadores da Escola de Frankfurt, resgatados em novos debates nas ciências sociais em geral.

Esta direção rumo ao um olhar mais aguçado ao detalhe, às nuances das pequenas coisas e situações, tem recebido maior visibilidade nos trabalhos que inserem as contribuições da fenomenologia e existencialismo nas análises geográficas (CORRÊA, 2009; MARINHO, 2016). Não há objeção às proposições de grande alcance pelas humanidades, pelo contrário, é a partir delas que houve grandes avanços epistêmicos e metodológicos em muitas das ciências sociais na atualidade, o que é colocado em relevo é o afastamento de áreas do saber como a História, Geografia, Economia e Sociologia para o indivíduo, o sujeito em sua diversidade, individualidade e, também, na relação com as coletividades que fazem parte.

Neste artigo a reflexão proposta está voltada à escala do cotidiano, em como voltarmos ao âmbito da realidade íntima e proximal com a qual interagimos. Este caminho de questionamento será trilhado pelo tema da facticidade e do cotidiano num 
primeiro momento, com foco na ocasionalidade dos seres, estares e aconteceres e sua transposição pela arte, especialmente pela linguagem escrita; posteriormente, a discussão se volta para a escala mínima, a espacialização do cotidiano e sua epifania como forma de singularizar o instante com a fenomenicidade posta numa instância situacional e as ocorrências fáticas proximais que a infiltram e definem espaçotemporalmente.

\section{FACTICIDADE E A EPIFANIA COTIDIANA}

Nos arranjos conceituais e categoriais da ciência e filosofia, muitas são as investidas na direção de como explicar o mundo, compreendê-lo, elaborando para tal objetivo grandes sistemas, estruturas e percursos teórico-metodológicos. Ao voltarmos a atenção ao âmbito proximal, posicionamos o pensamento no outro lado do espectro desta intenção reflexionante, de modo a tentar contemplar, ao máximo possível, cada detalhe presente no espaço de um instante ou na amplitude de uma extensão restrita, esta é a seara na qual nos deparamos com a facticidade cotidiana.

A facticidade é colocada, desta maneira, em suspensão analítica para o espanto da epifania de sua presença para nós e em nossa representação de mundo: “As veredas, as estradas, as ruas, as avenidas se constituem em tablados para o desempenho da liturgia de ser em meu repertório, ao ensejo da repetição que os protagonistas se me oferecem." (COUTINHO, 1976, p. 199). Coutinho (1976) também acrescenta a questão a infiltração do que o autor chama de padrões emotivos nesta singularização dos elementos que compõem as diversas paisagens da realidade objetiva, que representamos, interpretamos e fazemos parte:

A escala de meu vulto metrifica as possibilidades de interpretação de cada um dos protagonistas de forma que a reciprocidade de ser, de mim aos outros, dos outros a mim, se estabelece de conformidade com o módulo de minha receptiva, mesmo porque nada se propõe a corporificar-se em meu repertório sem deixar-se medir de acordo com os vãos deste receptáculo. As nominações, os temas que pairam em mim, e aos quais demandam os atores que se candidatam ou atendem à minha solicitação, têm, por sua vez, uma capacidade de aglutinação que se mensura ao compasso de meus padrões emotivos. (COUTINHO, 1976, p. 36). 
Em um outro plano epistemológico, com maior estofo argumentativo ao que foi defendido por Evaldo Coutinho, há as considerações de Martin Heidegger (2013) sobre a hermenêutica da facticidade. Segundo o filosófico alemão, é por este método de pensar e analisar o mundo que conseguiríamos chegar ao ser presente em cada ente, e sua contraparte ontológica: "A facticidade, isto é, o ser-aí próprio enquanto é questionado em seu caráter ontológico. A facticidade seria o modo de ser de nosso poder-ser mais próprio, modo que se expressa sempre e a cada vez "aí", na ocasionalidade.” (HEIDEGGER, 2013, p. 37).

Para melhor compreendermos estas considerações de Heidegger (2013) é preciso que aumentemos o alcance destas asserções. O Ser, a essência da totalidade, é inalcançável a nós, incapturável em sua extensão, duração, espessura ontológica e difusão como fonte das infinitas singularizações do existir. Por este motivo é que Heidegger (2013) não posiciona/encerra o ser situado no mundo, o ser-aí, que somos nós mesmos como abertura do Ser espaço-temporalmente delimitado: "O ser-aí próprio é o que é justamente e apenas em seu "aí" ocasional. Uma determinação da ocasionalidade é o hoje, o estar ou demorar-se sempre já no presente, apropriar-se sempre já dele. (Ser-aí na medida em que é histórico, seu presente." (HEIDEGGER, 2013, p. 37).

Michel de Certeau (1994) apresenta uma reflexão sobre a ocasião e o cotidiano, com camadas dialógicas às colocações de Heidegger (2008; 2013), mas o relevo trabalhado pelo francês está localizado na justaposição de eventos, dimensões e conjunturas que, juntas e correlacionadas, dão origem ao que o autor denomina como torsões situacionais, a ocasionalidade cotidiana em sua heterogeneidade:

A ocasião é um nó tão importante em todas as práticas cotidianas, como nos relatos 'populares' atinentes, que é preciso deter-se um pouco mais e precisar melhor este primeiro esboço. Mas a ocasião não cessa de enganar as definições, por não ser isolável nem de uma conjuntura nem de uma operação. Não é um fato destacável da 'volta' que o produz inscrevendo-se numa série de elementos, ela distorce as suas relações. Ela aí se traduz em torsões geradas numa situação pela aproximação de dimensões qualitativamente heterogêneas que não são mais apenas oposições de contrariedade ou de contradição. [...] permitem justapor, num mesmo quadro, espaços diferentes. Mas, na série em que se insinua a ocasião, a justaposição de dimensões heterônomas diz respeito ao tempo e ao espaço, ou estado e ação etc. Ela é marcada por relações proporcionalmente inversas, análogas àquelas que, em Pascal, articulam 'ordens' diferentes e são do tipo: 
tanto mais presente quanto menos visível; tanto menos numerosos quanto mais privilegiados pela graça, etc. Há qualitativamente passagens para a outra, por relações 'torcidas', por sucessivas inversões. (CERTEAU, 1994, p. 159).

Esta torsão espaço-temporal é o momento oportuno (Kairós, divindade grega ligada ao tempo ocasional, a oportunidade temporal), no qual a invisibilidade da ocasião prevalece sobre a ordenação que possa existir em determinada porção do espaço-tempo: “[...] onde o invisível saber escapa ao poder invisível.” (CERTEAU, 1994, p. 160); e esta preocupação, com a temporalidade oportuna entremeada ao dinamismo da realidade objetiva, é apresentada pelo autor quando menciona que: "Resta precisar ainda um último ponto, que é o essencial: como é que o tempo se articula num espaço organizado? Como se efetua sua "penetração" no modo de ocasiões? Em suma, qual a implantação da memória num lugar que já forma um conjunto?” (CERTEAU, 1994, p. $160)$.

E a resposta trazida por Certeau (1994, p. 161) está no equilíbrio entre as representações internas do tempo, memórias, com o saber construído sobre determinada situação específica, ocasional: "Este é o momento equilibrista e tático, o instante da arte. Ora, essa implantação não é localizada nem determinada pela memória-saber.” Haverá, desta maneira, uma postura kairológica, ou seja, de aproveitamento da ocasionalidade vivida, transparecida pelo pensar e agir, singularmente, engendrando os pormenores a mais em nosso mundo: "A ocasião é "aproveitada", não criada. É fornecida pela conjuntura, isto é, por circunstâncias exteriores onde um bom golpe de vista consegue reconhecer o conjunto novo e favorável que irão constituir mediante um pormenor a mais." (CERTEAU, 1994, p. 161).

A ocasião em sua multiplicidade manifesta-se a todo tempo, e em qualquer lugar. Novamente Coutinho (1976) volta a contribuir em sua dissertação sobre o lugar de todos os lugares que é e está em nós, ou seja, somos o ser aberto à sua própria compreensão, no ato de pensar sobre todos os entes, nós mesmos e o mundo em sua totalidade vista em cada uma de suas ocasiões, múltiplas e efêmeras, nas palavras de Heidegger (2013, p. 38): “Trata-se de ater-se à indicação a respeito do possível cumprimento do conceito de facticidade, que é dada previamente como seu possível encontro com a direção. O ser-aí próprio é o que é justamente e apenas em seu "aí" ocasional.” Há, nestes argumentos, a facticidade entendida como o cotidiano ordinário, 
que se extraordinariza pelo ser-aí em toda a extensão mundana, a fenomenicidade manifestada nos recortes fáticos do cotidiano: "Ser em um mundo, ser vivido pelo mundo; a cotidianidade presente." (HEIDEGGER, 2013, p.37).

Seguindo estas linhas de reflexões, Éric Dardel trabalha a ideia de circunstância, que pode ser correlacionada à noção de ocasionalidade de Heidegger (2013) e Certeau (1994): “A Terra é, por excelência, para o homem, como destino, a circunstância (circumstare), aquilo que se ergue à sua volta e mantém sua presença como engajamento no Ser" (DARDEL, 2011, p .42). A relação estabelecida para a circunstância, novamente, é trazida para a esfera do fator escalar, ou seja, do amplo para o singular de cada detalhe da realidade objetiva: "O distante e o próximo, a vertente ensolarada e a vertente sombreada, a fuga horizontal dos rios e dos campos, a vertical dos altos cimos, confirmam a todo instante a existência com sua presença, como espacialização do mundo, emersão acima das coisas." Por fim, o autor espacializa estes diferentes estares do ser humano em seu meio, com abertura ao ser em seus estares de Coutinho (1976), nas ocasionalidades da totalidade mundana: "O homem procura a Terra, ele a espera e a chama com todo o seu ser." (DARDEL, 2011, p .42).

Estas reflexões de Dardel (2011) incrementam e avançam na direção do que foi exposto até este momento, no que diz respeito à nossa aproximação às coisas, para entendê-las, melhor compreendendo os sentidos e significados dos entes e de nós mesmos. Há nestas considerações a escala íntima, a circunstância situacional mínima do cotidiano, das pequenas coisas, atos, decisões, concreções e abstrações criadas, reificadas, descontruídas e difundidas por nós, em ao viver diário. Como metodologia de análise dos recortes da fenomenicidade a existência é observada em suas camadas, possibilidades de ser e estar por meio da hermenêutica da facticidade proposta por Heidegger:

O tema da investigação hermenêutica é o ser-aí próprio em cada ocasião. O ser da vida fática mostra-se no que é no como do ser da possibilidade de ser de si mesmo. A possibilidade mais própria de si mesmo que o ser-aí (faticidade) é, e justamente sem que esta esteja "aí", será denominada existência. Através do questionamento hermenêutico, tendo em vista que ele seja o verdadeiro ser da própria existência, a faticidade situa-se na posição prévia, a partir da qual e em vista da qual será interpretada. Os conceitos que tenham origem nesta explicação serão denominados existenciais. (HEIDEGGER, 2013, p. 22). 
Nesta imersão do ser-aí em meio à totalidade ôntica é que se torna possível investirmos na emersão tanto da unicidade da abertura onto-ontológica permitida por esta singularidade como, também, a enunciação das propriedades dos demais entes existentes no mundo, cotidiano e facticidade, captando suas camadas e detalhamentos ocasionais e situacionais:

\begin{abstract}
O ser-aí humano - um ente disposto em meio ao ente, comportando-se em elação ao ente - existe de mais a mais de tal maneira, que o ente sempre se acha manifesto na totalidade. A totalidade não precisa ser propriamente concebida aí, seu "pertencimento" ao ser-aí pode estar velado, a amplitude deste todo é mutável. A totalidade é compreendida, sem que o todo do ente manifesto também tenha sido captado expressamente ou mesmo "exaustivamente" investigado em suas conexões específicas, regiões e estratos. A compreensão dessa totalidade, que é sempre antecipadora e abarcadora, é, porém, ultrapassagem em direção ao mundo. (HEIDEGGER, 2008, p. 169).
\end{abstract}

Mais do que enunciar o ser dos entes de si próprio, o indivíduo coloca-se e entende-se como ser-aí manifestado no mundo, daí a expressão consagrada de Heidegger ser-no-mundo, ou seja, a abertura da diferença ontológica, permitida pela linguagem enunciadora do ser humano, circunscrita espaço-temporalmente, situada nos recortes fáticos da cotidianidade fenomênica.

Esta situação é explorada por Dardel (2011) como um dos principais argumentos para uma apreensão existencial da extensão, do ser dos entes e o próprio ser-aí, trasladado ao mundo em sua ocasionalidade e facticidade: “A 'situação' de um homem supõe um 'espaço' onde ele 'se move'; um conjunto de relações e de trocas; direções e distâncias que fixam de algum modo o lugar de sua existência." E ainda completa o autor, sobre esta condição situacional do ser-aí humano: “"Perder a localização', é se ver desprovido de seu 'lugar', rebaixado de sua posição 'eminente', de suas 'relações', se encontrar, sem direções, reduzido à impotência e à imobilidade.” (DARDEL, 2011, p. 14). A localização perdida, ou múltipla, de que trata Dardel remete-nos aos lugares de Coutinho (1976) e a ocasião espacializada de Certeau (1994) e, também, ao ser-aí de Heidegger:

O ente, digamos a natureza no sentido mais amplo, não poderia se manifestar de maneira alguma, se não encontrar-se ocasião de entrar 
em um mundo. Por isto falamos de uma possível e ocasional entrada no mundo (Welteingang) do ente. Entrada no mundo não é algo que ocorre no ente que entra, mas algo que "acontece" "com" o ente. E esse acontecer é o existir do ser-aí, que como existente transcende. Somente quando, na totalidade do ente, o ente se torna "mais ente" sob modo da temporalização do ser-aí, é dia e hora da entrada no mundo pelo ente. E somente quando acontece esta história primordial, a transcendência, isto é, quando o ente com o caráter do ser-no-mundo irrompe para dentro do ente, existe a possibilidade de o ente se manifestar. (HEIDEGGER, 2008, p. 171)

Temos, portanto, o posicionamento existencial, o lugar na realidade objetiva como ser-aí localizado, não confinado mas manifestado no e pelo mundo. Cultivamos, habitamos e construímos nosso mundo, seja em concreções ou abstrações, edificações ou representações: "Igualmente imaginário é o fato de que, nas relações indicadas por habitar, construir, cultivar, circular a Terra é experimentada como base. Não somente ponto de apoio espacial e suporte material, mas condição de toda "posição" da existência, de toda ação de assentar e de se estabelecer (dde poser et de reposer)." (DARDEL, 2011, p. 40).

A imensurabilidade sígnica de uma existência no mundo perpassa, desta maneira, na potência da fenomenicidade como todo inalcançável - representada pelos autores aqui apresentados em nomeações que vão do ser-aí em seus estares-no-mundo, a ocasião oportuna, o cotidiano, e a situação -, passível apenas de recortes fáticos a serem postos em análise ou, em uma condição de melhor alcance da linguagem para as manifestações do existir no mundo, por meio da arte e criatividade, em diferentes formas de escriturações da existência no mundo.

\section{A LINGUAGEM ARTÍSTICA E AS ESCRITURAÇÕES EXISTENCIAIS}

Como a facticidade será posta em evidência frente à totalidade fenomênica? A resposta é proposta por Friedrich Nietzsche em sua Gaia Ciência [1882] (2012), quando suscita as diretrizes do que o filósofo considera uma nova forma de encarar o viver e o mundo, por meio da arte e da poesia, portadoras da irracionalidade criativa frente à retitude da racionalidade científica: "A bela e selvagem irracionalidade da poesia refutaos, a vocês, utilitaristas! Precisamos querer desvencilhar da utilidade alguma vez - isso elevou o ser humano, isso o inspirou para a moral e a arte" (NIETZSCHE, [1882] 2012, 
p. 104). Esta irracionalidade, condição liberta do ato criativo e da expressão artística, é que Nietzsche chamará de homo poeta:

153 Homo poeta - Eu mesmo, que fiz inteiramente só essa tragédia das tragédias, até onde ela possa estar pronta; eu, que primeiramente ateei o nó da moral na existência, e depois o apertei de forma tal que somente um deus o poderá desatar - como exige Horácio -, que próprio matei agora todos os deuses no quarto ato - por moralidade! Que será agora do quinto ato? De onde tirarei a solução trágica? Devo começar a imaginar uma solução cômica? (NIETZSCHE, [1882] 2012, p. 149)

Em outro momento, da mesma obra, Nietzsche propõe que nos afastemos das coisas, para que assim consigamos vê-las melhor, e diz mais, que é com os artistas que podemos aprender como atingir as coisas cotidianas, mínimas, sendo poetas-autores, vendo o mundo com novos olhos, por entre suas propriedades particulares. A linguagem, em suas múltiplas versões e variáveis de uso e expressão, é a via de expressão das representações de tudo o que nos cerca, com o que interagimos e, também, com as reações emocionais/psicológicas, é esta a inclinação para a arte, a qual se volta Nietzsche (2012):

299. O que devemos aprender com os artistas - De que meios dispomos para tornar as coisas belas, atraentes, desejáveis para nós, quando elas não são? - e eu acho que em si elas nunca o são! [...] Afastarmo-nos das coisas até que não mais vejamos muita coisa deles e nosso olhar tenha de lhes juntar muita coisa para vê-las ainda - ou ver as coisas de soslaio e como que em recorte - ou dispô-las de forma tal que elas encubram parcialmente umas às outras e permitam somente vislumbres em perspectivas - ou contemplá-las por um vidro colorido ou à luz do poente - ou dotá-las de pele e superfície que não seja transparente: tudo isso devemos aprender com os artistas, e no restante ser mais sábios do que eles. Pois neles esta sutil capacidade termina, normalmente, onde termina a arte e começa a vida; nós, no entanto, queremos ser os poetas-autores de novas vidas, principiando pelas coisas mínimas e cotidianas. (NIETZSCHE, [1882] 2012, p. 179-180).

O homo poeta não se reduz apenas aos poetas em sentido estrito, está mais próximo da ideia de expressão criativa por meio da linguagem artística. As pinturas, esculturas, música e dança, também fazem parte das representações poéticas de nosso mundo. O papel da escrita e literatura se sobressai pelo fato de por ela manifestar-se 
uma quantidade maior de registros, da criação artística: "Não resta dúvida que unicamente a arte literária teria condições para me favorecer nesse ponto de minha obra; nenhuma outra arte, se porventura eu possuísse os meios exigíveis, me concederia a flexibilidade, a ductilidade com que a literatura, por estear-se na imaginária interna, comunica, ao menos por aproximação" (COUTINHO, 1976, p. 183).

Coutinho (1976) realiza, ainda, uma reflexão que se aproxima da noção de poetas-autores de Nitezsche, quando diz que: “[...] o que o autor pretende desnudar sobre uma intuição de tipo imanente, à maneira desta que envolve a aglutinação do existenciador e do objeto de existência." (COUTINHO, 1976, p. 183). Apesar desta inclinação de protagonismo à literatura e escrita, Jacques Derrida (2017) nos alerta sobre o risco da linguagem escrita ser direcionada à um ponto relativista de seu potencial de representação sígnico: “[...] o conceito de escritura excede e compreende o de linguagem" (DERRIDA, 2017, p. 10). Para o autor, é preciso que tenhamos cautela com o estágio em que, atualmente, se encontra a ideia de escritura, por esta ser posta num patamar de detentora da "[...] ação, movimento, pensamento, reflexão, consciência, inconsciente, experiência, afetividade etc.” (DERRIDA, 2017, p. 10).

Em outros termos, o que preocupa o filósofo francês é onde estaria o pontolimite para a representação escrita da linguagem aos elementos sígnicos que compõem nosso mundo, já que há "[...] a tendência a designar por 'escritura' tudo isso e mais alguma coisa: não apenas os gestos físicos da inscrição literal, pictográfica ou ideográfica, mas também a totalidade do que a possibilita” (DERRIDA, 2017, p. 10-11).

Em concordância com as posições de Derrida (2017) Gomes (1997) nos apresenta seu entendimento do espaço como um texto, a ser descrito e lido, em suas múltiplas significações: “A análise geográfica deve examinar o espaço como um texto, onde as formas são portadoras de significados e sentidos, isto é, o arranjo espacial das coisas é uma linguagem." (GOMES, 1997, p. 25). E este uso da linguagem espacializada, no caso dos geógrafos e expressões pautadas nos arranjos espaciais, também é lembrado por Dardel (2011) quando o autor disserta que a: "Presença, presença insistente, quase inoportuna, sob o jogo alternado das sombras e da luz, a linguagem do geógrafo sem esforço transforma-se na do poeta.” E o autor nos oferece a deixa para a expressão artísticalpoética como via de acesso aos estratos de significância do mundo, em sua totalidade fenomênica ou recortes fáticos, fazendo emanar, por 
diferentes linguagens, os sentidos de suas grafias: "Linguagem direta, transparente, que "fala" sem dificuldade à imaginação, bem melhor, sem dúvida, que o discurso "objetivo" do erudito, porque ela transcreve fielmente o "texto" traçado no solo." (DARDEL, 2011, p. 3).

As palavras|grafias possuem este papel de ser uma tentativa de abarcar as propriedades dos entes que nomeiam, nem sempre atingindo tal objetivo, porque o sentido de fato, é passageiro, efêmero e escapa aos signos: "A condenação das palavras origina-se da incapacidade da linguagem de transcender o mundo dos opostos relativos e interdependentes, do isto em função do aquilo. [...] Com efeito, o sentido aponta para as coisas, assinala-as, mas jamais as alcança. Os objetos estão mais além das palavras.” (PAZ, 1982, p. 128). Octávio Paz, ainda complementa sua reflexão, trazendo a questão das múltiplas versões do real criadas por nós, para representar o mundo em suas singularidades e diversidade:

Todas as nossas versões do real - silogismos, descrições, fórmulas científicas, comentários de ordem prática, etc. - não recriam aquilo que pretendem exprimir. Limitam-se a representá-lo ou descrevê-lo. Se vemos uma cadeira, por exemplo, percebemos instantaneamente sua cor, sua forma, os materiais com que foi construída, etc. A apreensão de todas essas características dispersas não é obstáculo para que, no mesmo ato, nos seja dado o significado da cadeira: o de ser um móvel, um utensílio. Mas, se queremos descrever nossa percepção da cadeira, teremos de ir aos poucos e por partes: primeiro sua forma, depois sua cor, e assim sucessivamente até chegar ao significado. No curso do processo descritivo foi se perdendo pouco a pouco a totalidade do objeto. A princípio a cadeira foi apenas forma, mais tarde uma certa espécie de madeira, e finalmente puro significado abstrato: a cadeira é um objeto que serve para sentar. No poema a cadeira é uma presença instantânea e total, que fere de um golpe a nossa atenção. O poeta não descreve a cadeira: coloca-a diante de nós. (PAZ, 1982, p. 132).

Verifica-se que mesmo na esteira do risco ao relativismo da ideia de escritura colocado por Derrida (2017) o caráter inalcançável da realidade, do fenômeno e seus recortes, ainda permanece como epicentro do debate proposto. Se expandirmos este pensamento sobre as versões do real, da facticidade cotidiana e as epifanias dos objetos, chegaremos no cruzamento de toda a reflexão, pautada pela escala da representação, erigida por entre as grafias da existência em sua extensão mundana. 
O mínimo dimensional é entendido como o desafio ao que foi exposto até este momento, agregando consigo elementos de complexificação no que se refere às tentativas de descrição das propriedades ontológicas dos entes, suas essências e sentidos, em uma proximidade considerável com que foi amplamente trabalhado por Hartmann $(1953 ; 2019)$ em seus estudos ontológicos.

E é na direção deste mínimo escalar e dimensional, como pensamento e método, que devemos nos voltar neste momento da reflexão proposta, para que assim possamos esboçar a via a ser trilhada rumo às singularidades e unicidades presentes na diferenciação onto-ontológica da facticidade e do cotidiano.

\section{A ESCALA MÍNIMA}

Após a exposição feita até aqui, sobre o cotidiano e a facticidade, bem como as grafias e escriturações dos seres e estares na totalidade fenomênica, é possível seguirmos em direção ao cerne conceitual que fundamenta este posicionamento teórico e metodológico, ou seja, a escala mínima. Em termos mais objetivos, trata-se de pensar o sujeito em sua extensão singular, o alcance do seu corpo e pensamento, do seu agir e consciência, da reverberação das suas ações e potencial de significação, e as representações e interpretações inerentes à intencionalidade. Como aporte à esta condição mínima da escala do indivíduo, há os escritos de Merleau-Ponty (1971), sobre a visibilidade e invisibilidade dos entes e suas essências para a consciência do sujeito que os percebe, pensa e significa:

O mundo é o que percebo, mas sua proximidade absoluta, desde que examinada e expressa, transforma-se também, inexplicavelmente, em distância irremediável. O homem "natural" segura as duas pontas da corrente, pensa ao mesmo tempo que sua percepção penetra nas coisas e que se faz aquém de seu corpo. Se, todavia, na rotina da vida, as duas convicções coexistem sem esforço, tão logo reduzidas a teses e enunciados, destroem-se mutuamente, deixando-nos confundidos. (MERLEAU-PONTY, 1971, p. 20).

O autor ainda complementa sua reflexão, direcionando-a para o núcleo da temática a percepção do mundo: "Vejo, sinto e é certo que, para me dar conta do que seja ver e sentir, devo parar de acompanhar o ver e o sentir no visível e no sensível onde 
se lançam, circunscrevendo, aquém deles mesmos um domínio que não ocupam” E ainda complementa o autor, quando diz que: "[...] partir do qual se tornam compreensível segundo seu sentido e sua essência.” (MERLEAU-PONTY, 1971, p. 44).

E como compreender estas significâncias múltiplas e imensuráveis, percebidas por nós? que contém os sentidos de singularização do nosso mundo, subjetividade e consciência? Merleau-Ponty diz que: "Compreendê-los é surpreendê-los, pois a visão ingênua me ocupa inteiramente, pois a atenção na visão, que se acrescenta a ela, retira alguma coisa desse dom total, sobretudo, porque compreender é traduzir em significações disponíveis m sentido inicialmente cativo na coisa e no mundo." (MERLEAU-PONTY, 1971, p. 44). E, neste ponto, há uma linha de conexão aos argumentos expostos anteriormente de autores como Certeau (1994), Heidegger (2013), Derrida (2017) e Coutinho (1976) que defendem esta postura de valoração dos traços da realidade como expoentes da significação do existir em sua efemeridade cotidiana.

O que propõe Merleau-Ponty (1971) é uma postura de análise de como nós, enquanto sujeitos que significam o mundo, passamos para as coisas do mundo sua singularidade. Epifaniamos os entes, seja um gesto, um objeto, uma lembrança, um breve acontecimento. $\mathrm{O}$ autor disserta ainda sobre uma aproximação real às coisas, aos entes, para que possamos chegar ao seu ser, suas propriedades singularizantes:

Compreende-se então por que, ao mesmo tempo, vemos as próprias coisas no lugar em que estão o ser-percebido, e estamos afastados delas por toda a espessura do olhar e do corpo: é que essa distância não é o contrário dessa proximidade, mas está profundamente de acordo com ela, é sinônima dela. É que a espessura da carne entre o vidente e a coisa é constitutiva de sua visibilidade para ela, como de sua corporeidade para ele; não é um obstáculo entre amos, mas o meio de se comunicarem. Pelo mesmo motivo, estou no âmago do visível e dele me afasto: é que ele é espesso, e, por isso, naturalmente destinado a ser visto por um corpo. O que há de indefinível no quale, na cor, nada mais é que uma maneira breve, peremptória, de produzir num único algo, num único tom de ser, visões passadas, visões vindouras, e aos cachos. Eu, que eu vejo, também possuo minha profundidade, apoiado neste mesmo visível que vejo e, bem o sei, se fecha atrás de mim. Em vez de rivalizar com a espessura do mundo, a de meu corpo é, ao contrário, o único meio que possuo para chegar ao âmago das coisas, fazendo-me mundo e fazendo-as carne. (MERLEAU-PONTY, 1971, p. 132). 
Se utilizarmos a terminologia de Merleau-Ponty (1971) quando este menciona ideia de quale podemos relacionar, para a discussão trabalhada até este momento, outros autores que tratam desta trilha em busca do ser dos entes. Segundo Gaston Bachelard (2008) este exercício de ir aos entes em sua minuciosidade, compostos pela carga imaginária singular de cada um de nós, não cabe ao pensamento reto e frio, é preciso fornecer a abertura imaginárialemocionallsingularizante nestas espacialidades: " $\mathrm{O}$ espaço percebido pela imaginação não pode ser o espaço indiferente entregue à mensuração e à reflexão do geômetra. É um espaço vivido. E vivido não em sua positividade, mas com todas as parcialidades da imaginação.” (BACHELARD, 2008, p. 19).

Bachelard (2008) também possui, em suas considerações, uma preocupação com a interioridade, que o autor denomina imensidão íntima, que está em nós, e é projetada ao mundo externo pelas nossas representações e significações: “[...] a imensidão está em nós" (BACHELARD, 2008, p. 190) e completa o filósofo francês, sobre esta vastidão interior dizendo que "[...] a grandeza progride no mundo à medida que a intimidade se aprofunda" (BACHELARD, 2008, p. 200).

O que defende Bachelard (2008) vai ao encontro com o exposto até este ponto da reflexão, ou seja, para a análise da facticidade em suas singularidades, os recortes mínimos do cotidiano: “Todas as coisas pequenas exigem vagar. [...] É preciso amar o espaço para descrevê-lo tão minuciosamente como se nele houvesse moléculas de mundo, para enclausurar todo um espetáculo numa molécula de desenho" (BACHELARD, 2008, p. 167). Representação, imaginação e a escala mínima dos pequenos detalhes do cotidiano em suas imensuráveis significações, este é o ponto em destaque pelo autor:

Assim, se seguirmos com simpatia o poeta da miniatura, se tornamos o trenzinho do pintor preso, a contradição geométrica fica redimida, a Representação é dominada pela Imaginação. A Representação não é mais que um corpo de expressões para comunicar aos outros nossas próprias imagens. Na linha de uma filosofia que aceita a imaginação como faculdade de base, pode-se dizer, à maneira de Schopenhauer: "O mundo é a minha-imaginação". Possuo melhor o mundo na medida em que eu seja hábil em miniaturizá-lo. Mas, fazendo isso, é preciso compreender que na miniatura os valores se condensam e se enriquecem. Não basta uma dialética platônica do grande e do pequeno para conhecer as virtudes dinâmicas da miniatura. É preciso 
ultrapassar a lógica para viver o que há de grande no pequeno. (BACHELARD, 2008, p. 295).

A retidão geométrica aqui, é posta em choque com a ideia de uma epifania do cotidiano, uma elevação da significância das pequenas coisas, argumento visto também no trabalho de Maria Laura Silveira (2006) sobre as perspectivas geométrica e existencial. Mas ressalta-se que as considerações da autora estão inclinadas às diretrizes radical e crítica do pensamento geográfico, cujo balizador para suas argumentações e análises são os movimentos da economia política no espaço:

Em geral, no período contemporâneo, as idéias de distância, limite,
fronteira são postas em questão. Num mundo assim construído e,
ainda, com a força da ação de alguns agentes e de suas respectivas
formas de discurso, muitas dessas distâncias foram superadas, levando
a uma reformulação de limites, a uma necessária resignificação dos
conceitos da nossa disciplina e a um conjunto de novos conceitos,
dentre os quais, parece-nos, o conceito de rede desponta com muita
força no nosso vocabulário. Nessa sucessão de contextos, ontem e
hoje muitas geografias permanecem atreladas a uma visão do espaço
como continente, uma concepção geométrica, feita de velhos e novos
conceitos que privilegiam a distância. O centro da reflexão
epistemológica parece ser a extensão, um conceito-chave ou, mesmo,
uma categoria, que leva a uma resignificação do vocabulário
tradicional. (SILVEIRA, 2006, p. 82).

De opinião alinhada à de Silveira (2006) há os argumentos de Gomes (1997, p. 25) quando diz que: "A descrição simples da forma não pode dar conta de todos os significados e todas as práticas sociais que tem sede aí." E o autor complementa este apelo à inerente condição não-geométrica da complexidade existente na relação entre o indivíduo e as coletividades com o meio que habitam e interagem: "Parece que tão pouco nos interessa a geometria se não a relacionarmos às relações sociais, conflitos, usos e contextos sob os quais esta forma existe e resiste em tempos diversos. O visível depende assim dos nossos óculos conceptuais." (GOMES, 1997, p. 25).

Estas observações de Silveira (2006) e Gomes (1997) somam-se às proposições de Barcellos (1995) e Marinho (2016) sobre os territórios do cotidiano, no sentido de transporem à geometricidade ôntica. O desafio posto está em buscar a ontologia da facticidade, captar no âmbito fenomênico, mesmo que por um instante, as propriedades definidoras de cada ente, representações de nosso mundo. Nesta trilha da ontologia das 
narrativas do cotidiano, Suzuki (2006); e Suzuki (2017) trabalha com uma exploração das dialogias possíveis entre o texto literário com o contexto geográfico (as grafias espaciais), talhando as marcas existenciais expostas em obras que permitem o caminhar por esta profícua ponte de análise do cotidiano.

\section{ILUSTRAÇÕES LITERÁRIAS}

Apesar de haver uma considerável gama de autores, obras e amplo histórico de discussão e desenvolvimento da Fenomenologia e Existencialismo, as contribuições fenomenológicas de Gaston Bachelard e Maurice Merleau-Ponty -são, normalmente, as que possuem maior impacto e presença nos estudos geográficos sobre a existência, a subjetividade e os significados das representações do sujeito no espaço. Mais do que apresentar em grau de complexidade à existência em sua singularidade cronotópica, é preciso caminhar na direção de uma metodologia possível de análise dos traços, marcas e nuances dos seres e estares.

Neste sentido, de uma construção teórico e metodológica na direção da escala mínima do cotidiano e da facticidade, observe-se, por exemplo, um interessante exercício de hermenêutica da facticidade, feito por Martin Heidegger (2008; 2013) que vai ao encontro das reflexões de Merleau-Ponty (1971) e de Bachelard (2008), em um sentido mais de aplicação da fenomenologia do cotidiano e epifania dos objetos, tendo a escala mínima dos sujeitos como ponto de partida para tal analítica da existência e do existir:

Pela pintura de Van Gogh não podemos nem verificar onde ficam os sapatos. (...) Um par de sapatos de camponês e nada mais. E todavia, da escura abertura do gasto interior do calçado olha-nos fixamente a fadiga do andar do trabalho. Na dura gravidade do calçado retém-se a tenacidade do lento caminhar pelos sulcos que sempre iguais se estendem longe pelo campo, sobre o qual sopra um vento agreste. No couro fica a umidade e a fartura do solo. Sob as solas demove-se a solidão do caminho do campo pelo final da tarde. No calçado vibra o quieto chamado da terra, sua silenciosa oferta do trigo maduro, sua inexplicável recusa na desolação do campo no inverno. Por esse utensílio passa o calado desassossego pela segurança do pão, a alegria sem palavras por ter mais uma vez suportado a falta, a vibração pela chegada do nascimento e o tremor ante o retorno da morte. À terra pertence esse utensílio e no mundo da camponesa ele é abrigado. É 
dessa abrigada pertença que o próprio utensílio ressurge para seu repousar em si. (MOOSBURGER, 2007, p. 20).

Este exercício analítico das propriedades singularizantes de um objeto qualquer feito por Moosburger (2008; 2013), de acordo com as reflexões de Martin Heidegger sobre a obrada de arte pode ser estendido a outras exemplificações, no que o autor denomina como hermenêutica da facticidade. Em uma paisagem mais ampla também pode-se buscar os elementos que a singularizam frente à totalidade ôntica da qual faz parte e fornece os entes e suas essências, mas é preciso o momento de atenção, de tradução destes elementos, como diria Merleau-Ponty (1971), surpreendendo-os, retirando-os de seu caráter ôntico ordinário para suas especificidades ontológicas.

Se Heidegger (2008; ) caminha na direção do foco único, de um ente específico tocado pelo ser-aí, em meio à uma totalidade ôntica específica, há exemplos de extração artística das propriedades ontológicas em campos abertos de análise, como as paisagens. Obras como As Cidades Invisíveis de Ítalo Calvino e as Ficções de Jorge Luis Borges podem ser lembradas como exemplos deste exercício de emanação das singularidades ôntica na totalidade fenomênica. A seguir, apresenta-se um recorte, que serve como exemplo desta movimentação onto-ontológica frente à paisagem feita por Nietzsche (2012) em sua Gaia Ciência:

Toda essa região abunda nesse magnífico, insaciável egoísmo da avidez de posse e de pressa; e, tal como esses homens não reconheciam fronteiras na distância, instaurando, em sua sede de novo, um Novo Mundo junto ao Antigo, também na terra natal cada um se rebelava contra o outro e inventava um modo de exprimir sua superioridade e de por entre si e seu vizinho e sua infinitude pessoal. Cada um conquistava novamente para si a sua terra natal, ao subjugála com suas ideias arquitetônicas e como que transformá-la em pasto para seus olhos. No Norte impressiona a regra e o gosto geral pela regularidade e a obediência, quando observamos a forma de construção das cidades: intuímos a propensão a igualar-se e ajustar-se que deve ter dominado a alma dos construtores. [...] (NIETZSCHE, [1882] 2012, p. 174-175).

Partindo destas argumentações de Heidegger (2008; 2013) e Nietzsche (2012), é possível fazer a passagem ao ponto-limite da reflexão proposta neste artigo, referente à escala mínima, ao cotidiano em sua facticidade posta em relevo ontológico. Nos dois 
casos apresentados, no primeiro há um exercício dos pequenos objetos e situações e, no segundo, o da multíplice significação presente nos elementos de uma paisagem.

A seguir há duas ilustrações para uma analítica do cotidiano em sua facticidade, de modo a por em destaque e visualização de uma metodologia que permita efetuar o esforço de compreensão escalar do cotidiano, em sua relação onto-ontológica, passível de execução por nós, sujeitos que dão ao mundo seus aspectos de unicidade.

\subsection{Primeira ilustração para uma analítica do cotidiano e da facticidade}

Heidegger (2013) propõe os passos da hermenêutica da facticidade em direção à escala mínima, utilizando o exemplo de um ente específico e, a partir da seleção de um recorte fático e ôntico, faz um exercício fenomenológico e ontológico deste ente. Seguese uma primeira exposição do autor, especificamente sobre a cotidianidade e as coisas que a compõe:

Consideremos a cotidianidade mais absoluta: ao demorar-se em casa, ao encontrar-se num quarto, onde finalmente se encontra algo assim como "uma mesa"! Como isso ou aquilo vem à mesa-encontro? Tratase de uma coisa no espaço; enquanto tal coisa espacial é também algo material. Pesa tanto, tem tal cor, tal forma, a tampa é quadrada ou redonda; mede anto de altura, tanto de largura, sendo sua superfície suave ou grossa. É possível desfazer a coisa em pedaços, é possível queimá-la ou destruí-la de qualquer outra maneira. Essa coisa espacial e material, que se apresenta de tal maneira segundo os diferentes aspectos possíveis da sensibilidade, mostra-se sempre em sua "ocorrência" apenas a partir de um lado determinado, de tal modo que o aspecto desse lado se funde continuamente com os dos outros lados, prefigurados graças à configuração espacial da coisa; e assim com todos e cada um dos lados. (HEIDEGGER, 2013, p. 90).

Em outro momento, Heidegger (2013) disserta sobre a diversidade das coisas, e a valoração destes entes por nossas consciências, por meio de múltiplas representações. As objetualidades do cotidiano, desta forma, são valoradas por nós e, novamente, há a proximidade com o ente, para que possamos chegar ao sentido ontológico destes entes, os seus substratos de sentido:

Os diversos aspectos mostram-se e descobrem-se sempre de novo uns após os outros, dando voltas em torno da coisa; em cada caso, um diferente aspecto se apresenta, quer observando a partir de cima, quer 
observando a partir de baixo. Os próprios aspectos mudam segundo a iluminação, distância e demais fatores relativos em relação à posição do observador. O modo de ser-aí dessa coisa determinada e concreta em carne e osso proporciona a possibilidade de deduzir algo acerca do sentido ontológico e realidade de tais objetualidades. Tais objetualidades são propriamente as pedras e demais coisas da natureza. No entanto, quando é vista com uma maior proximidade, a mesa é algo mais; ela não é somente uma coisa espacial e material, mas está provida também de determinados predicados de valor: está bem-feita, é útil e funcional; é um aparato, um móvel, uma peça de mobiliário. O domínio universal do real pode ser dividido, portanto, em dois reinos: coisas naturais e coisas de valor, tendo sempre as coisas de valor, enquanto substrato de seu ser, o ser como uma coisa natural. (HEIDEGGER, 2013, p. 90).

Outro passo fundamental para a hermenêutica da facticidade, de acordo com Heidegger (2013) é a espacialização dos entes, sua alocação no mundo, o estar-aí mais até que o ser-aí, porque no primeiro caso o movimento de significação em seu devir se torna mais palatável, fenomênico enquanto impossibilidade de captação absoluta pelo sujeito. O uso, funcionalidade e modulação do porquê existir seriam, segundo o autor, as propriedades que deveriam ser buscadas pela dissecação da espessura do ente:

O ser próprio da mesa é: coisa material no espaço. [...] Na lida atenta ou entretida não se encontra concretamente nada em absoluto do que foi dito na descrição anterior e, se porventura houvesse algo, seria de uma maneira bem distinta. Tomemos o "mesmo" exemplo, o mesmo que se diz a respeito deste assunto, e comecemos a descrição de maneira que o primeiro que aparece, antes do nexo fenomenal, seja uma multiplicidade de fenômenos que se correspondem mutuamente. Será a análise subsequente que fará com que o nexo se destaque. No quarto está aí esta mesa aqui (não "uma" mesa qualquer entre muitas outas mesas ao lado de outas moradias e casas), na qual alguém se senta para escrever, comer, costurar ou para jogar. É algo que se vê nela imediatamente, por exemplo, quando se vai de visita: é uma mesa de escritório, uma mesa para refeição, uma mesa de costura; a mesa vem ao encontro inicialmente em si mesma dessa maneira. Não é que se lhe acrescenta o caráter de ser "para algo" como resultado de uma comparação com algo diferente do que ela é. O estar aí da mesa, no quarto, quer dizer: à medida que é usada dessa ou daquela maneira desempenha tal função; esta ou aquela coisa dela é "pouco prática", inadequada; tal outra está danificada; agora está melhor que antes no quarto, por exemplo, possui uma melhor iluminação; antes mesmo não ficava ou estava tão bem (para...). A mesa apresenta alguns riscos aqui e ali - na mesa, as crianças fazem suas tarefas, é nela que elas se ocupam; estes riscos não são interrupções quaisquer da pintura, ao contrário: foram feitos pelas crianças e continuam sendo delas. Este lado não é o lado leste, nem o lado estreito é tantos centímetros mais 
curto que o outro, mas é o lado em que se senta a mulher ao anoitecer quando ainda deseja ler; nesta mesa levamos outrora uma discussão ao respeito disso ou daquilo; aqui tomamos outrora tal decisão com um amigo, aqui foi escrito outrora tal trabalho, celebrou tal festa. (HEIDEGGER, 2013, p. 91).

As coisas, a onticidade deve vir ao nosso encontro, aproximar-se de nós. Estes entes, concretos ou abstratos, portarão os sentidos do nosso mundo representado, interpretado e reificado pela intencionalidade e subjetividade. A escala mínima do existir individual se manifesta como singularidade em cada propriedade ontológica dos entes apreendidos pela consciência:

Esta é a mesa, é assim que ela está aí na temporalidade da cotidianidade e, como tal, voltará a vir provavelmente ao encontro dentro de muitos anos, quando se encontrar virada ao chão, posta de lado inutilizada, como tantas outras "coisas", por exemplo, um brinquedo, danificado e quase irreconhecível - é a minha juventude. Num canto do porão encontra-se de pé um par de velhos esquis; um deles está quebrado ao meio; o que está aí não são coisas materiais com diferentes comprimentos, mas os esquis de certa época, com os quais alguém realizou manobras e percursos arriscados dessa ou daquela maneira. Este livro que tenho aqui é um presente de fulano; este ali foi encadernado em tal gráfica; este outro precisa ser levado para a encadernação; este precisa ser levado proximamente até ele; com este me debati longamente; este ali foi uma aquisição inútil, uma decepção; este outro, no entanto, preciso lê-lo; esta biblioteca não é tão boa como a de fulano, mas muito melhor que a biblioteca de sicrano; o assunto não é daqueles que alguém se identifique com ele; o que dirão os demais dessa apresentação, e assim por diante. Tais são os caracteres do vir ao encontro. Agora é necessário perguntar como constituem o ser-aí no mundo. (HEIDEGGER, 2013, p. 91-92).

O término da exposição de Martin Heidegger (2013) é efetuado com um questionamento, sobre o ser-aí no mundo. Este é o ponto, a partir do qual, devemos seguir, quando se trata de uma hermenêutica da facticidade, a busca pelo quale dos entes, a epifania dos objetos e a espessura, fazendo uso de expressões consagradas de Merleau-Ponty, das efemeridades na extensão de cada ocasião apartada, analiticamente, da totalidade fenomênica.

Este posicionamento de Heidegger vai na direção da mundaneidade imensurável como aporte de preenchimento do existir - e na obra do autor são encontradas diferentes referências poéticas que atestam tais argumentos do filósofo alemão, especialmente seus elogios e remissões à passagens de nomes como Rainer Maria Rilke e Friedrich 
Holderlin, expoentes da poesia nos pequenos detalhes do existir -, tendo as marcas, grafias, seres e estares, como meios pelos quais o ser-aí e o estar situacional cotidiano erige sua significação, seus sentidos em cada detalhe e mínima repartição da realidade objetiva passada da imanência ôntica à transcendência ontológica.

\subsection{Segunda ilustração para uma analítica do cotidiano e da facticidade}

Expõe-se outro exemplo de analítica existencial, desta vez com uma projeção literária, realizada por Simone de Beauvoir (2014), em seu conto A Idade da Descrição. Se com Heidegger (2013) a proposição é a de um preenchimento de significância do nosso mundo, pelas propriedades dos entes ao nosso redor em suas singularidades, com Beauvoir (2014) a reflexão vai no sentido contrário, ou seja, quando a facticidade do cotidiano não nos toca ou afeta, isolando-nos numa nadificação, fazendo-nos questionar pelo sentido em si de estar diante deste nosso mundo representado, e das coisas nele existentes, e a nós mesmos no ínterim desta totalidade. Vejamos um primeiro recorte da obra de Beauvoir:

Reflexos, ecos se encadeando ao infinito. Descobri a doçura de ter atrás de mim um longo passado. Não tenho tempo de contá-lo a mim mesma, mas às vezes, de improviso, eu o percebo em transparência ao fundo do momento presente: ele lhe dá sua cor, sua luz, como as rochas e as areias se refletem na cintilação do mar. Antigamente, eu me embalava com projetos, com promessas. Agora, a sombra dos dias mortos torna mais suaves emoções e prazeres. (BEAUVOIR, 2014, p. 16).

Percebemos que a autora realiza uma reflexão sobre o tempo interior, kairológico - assim como disserta, em seus argumentos do cotidiano, o filósofo Michel de Certeau (1994) -, frente à grande areia temporal que nos foge e na qual estamos inseridos. Outro ponto de destaque é sua visão sobre as promessas, porque elas guardam a retenção do futuro como possibilidade, e há a potencialidade pela frustração na não chegada aos objetivos dispostos e, desta maneira, o risco do sentido do viver se esvair aumenta, e o cotidiano se direciona ao sem sentido, à esta nadidade:

A tristeza recaiu sobre mim e não mais me deixou. De agora em diante, se me atraso na cama, é que me custa acordar sem o auxílio de 
incentivo para a vida. Hesitava em mergulhar sozinha na monotonia do dia. Uma vez de pé, ficava tentada a tornar à cama e lá permanecer até a noite. Atirava-me ao trabalho, ficava horas seguidas à mesa de escrever, nutrindo-me de suco de frutas. Quando parava, ao fim da tarde, tinha a testa escaldante e os ossos doloridos. Acontecia-me adormecer tão pesadamente sobre o divã que, ao acordar, experimentava um angustiante estupor: tal como se minha consciência, emergindo anonimamente da noite, hesitasse antes de se reencarnar. Ou era o cenário familiar que eu contemplava com olhos incrédulos: avesso ilusório e cintilante do Nada onde mergulhara. Meu olhar detinha-se surpreendido sobre os objetos que eu trouxera dos quatro cantos da Europa. O espaço não conservou o rastro de minhas viagens, minha memória negligencia evocá-las. E as bonecas, os vasos, as bugigangas estão por aí. Um nada me fascinava e obsedava. O encontro de uma seda vermelha e de uma almofada roxa. Quando vi pela última vez brincos de princesa, sua batina de bispo e cardeal, seu longo e frágil sexo? o volubilis luminoso? a simplória rosa selvagem? as madressilvas descabeladas? os narcisos abrindo em suas brancuras os grandes olhos espantados? quando? Eles podiam não mais existir no mundo e eu não o saberia. Nem os nenúfares nos açudes, nem o trigo mourisco nos campos. A terra está ao meu redor como uma vasta hipótese que jamais verifico. Eu me arrancava a essas brumas, descia nas ruas, olhava o céu, as casas mal caiadas. (BEAUVOIR, 2014, p. 16).

Aqui vemos a floresta de objetos, os entes em sua quantidade que nos foge no fenômeno das trivialidades sem fim, o cotidiano em seu estado puro, inalcançável à qualquer exercício de análise, o mais exímio que possa ser elaborado e posto em prática. O pensamento de Beauvoir (2014) encontra-se, desta maneira, muito próximo das colocações de Sartre (2016) sobre o mesmo tema, chamado pelo filósofo francês de campo central da estrutura egológica: "Em um sentido é um nada, uma vez que todos os objetos físicos, psicofísicos e psíquicos, toda as verdades, todos os valores estão fora dele, já que meu Moi, cessou, ele mesmo, de fazer parte dele. Mas esse nada é tudo, pois é consciência de todos esses objetos." (SARTRE, 2016, p. 61). Para Beauvoir (2014), o meio é colocado como uma possibilidade de existência, um projeto não desfrutado, ou se assim o foi, sem atingir seu estado máximo de sentido:

Nada me tocava. Luares e crepúsculos, cheiro de primavera molhada, de alcatrão quente, claridade e estações. Conheci momentos com puro brilho de diamantes, mas sempre sem o haver solicitado. Eles surgiam de surpresa, trégua inesperada, promessas insuspeitas, através dos trabalhos que me afligiam; eu os fruía fugidamente, saindo do liceu ou da boca do metrô, no meu terraço entre duas seções de trabalho, sobre o bulevar, quando me apressava para ir ao encontro de André. Agora, 
caminhava em Paris, disponível, atenta e gelada de indiferença. O excesso de meus lazeres, concedendo-me o mundo, impedia-me de vêlo. De igual maneira pelas tardes quentes, o sol incidindo nas persianas cerradas faz brilhar para mim todo o esplendor do estio e ele me cega se eu o afronto em sua crueza tórrida. (BEAUVOIR, 2014, p. 48-49).

O mundo é indiferente à existência, nosso existir. Nem mesmo o puro brilho de diamantes de momentos avulsos do cotidiano foram suficientes para tocar este estar entre as coisas, o ser-no-mundo, é uma visão inversa ao que foi tratado por Heidegger (2013) e apresentado no início deste trabalho. Por fim, novamente com a temática da temporalidade, Beauvior (2014) reflete sobre o efêmero do acontecer, o escapismo do instante de cada fato, ocasião, relances de um existir que deserta em seu vazio:

No oceano do tempo, eu era o rochedo batido pelas vagas que se renovavam e que não se move e não se gasta. E, súbito, o fluxo me arrasta e me arrastará até que eu tombe na morte. Tragicamente, minha vida se precipita. E, entretanto, ela se escoa neste momento com que lentidão - hora por hora, minuto por minuto! É preciso sempre esperar que o açúcar derreta, que a lembrança se apague, que a ferida se cicatrize, que o sol se ponha, que o tédio se dissipe. Estranho corte entre esses dois ritmos. Meus dias me escapavam aos galopes e em cada um deles eu enlanguescia. (BEAUVOIR, 2014, p. 54-55).

Em suma, chega-se a um devir, uma continuidade, o inalcançável da fenomenicidade dos fatos, não havendo um início definido ou um fim ao qual se destina chegar, pelo contrário, a metodologia de análise do cotidiano leva em conta a sua impossibilidade de fazê-lo. Como fim, a facticidade cotidiana e a escala mínima apesar de cognoscíveis são inalcançáveis filosófica ou cientificamente, esta é a abertura em que encontramos a arte, em todas suas linguagens.

A escola francesa da fenomenologia existencial possui autores e obras, filosóficas e literárias, que enveredaram sobre esta temática do cotidiano, rumo à escala mínima de significação do mundo pelo sujeito. Albert Camus, em suas metáforas filosóficas nos oferece o absurdo do existir e o mito de Sísifo como elementos de análise para esta condição; Jean-Paul Sartre, especialmente em seus contos, peças e romances, traz reflexões sobre a inserção das ações cotidianas no grande projeto histórico, elemento este que distinguiria seu existencialismo dos demais. 
Há em igual riqueza de contribuições, romances e contos da escola literária eslava que podem ser enquadrados como fazendo parte deste grande movimento de exploração da consciência humana e suas reações, sensações e interações mais íntimos com o meio, ou seja, o cotidiano e sua facticidade. O desafio posto é relacionado a inclinação real de cairmos em um subjetivismo ou solipsismo nos estudos das significações e singularizações quando se volta ao cotidiano (GABRIEL, 2010).

O subjetivismo e solipsimo são situações epistêmicas que podem ocorrer nesta linha metodológica, pelo fato de haver uma exploração da consciência e da subjetividade do sujeito no mundo. A questão posta deve ser a respeito do ponto até o qual podemos, ou conseguirmos chegar, para que não sejamos direcionados a um paradoxo de Zenão sobre a significância do mundo representado pela consciência; isto fica claro no exemplo dos passos feitos por Heidegger (2013), para que alcancemos o quale como diria Merleu-Ponty (1971), a penetração ocasional de Certeau (1994) e o poético na espacialidade pensada por Bachelard (2008).

Outros autores trabalharam intensamente sobre este detalhamento do âmbito mundano do sujeito, seu cotidiano e facticidade do ponto de vista de seu esvaziamento de sentido, como Franz Kafka, Albert Camus, Herman Hesse, Fiódor Dostoievski, Paul Auster, Chuck Palahniuk, as recentes obras de Patrick Modiano. Graciliano Ramos como representante nacional pode ser enunciado como exemplo na construção de obras que tratam do esvaziamento dos sentidos do mundo nas emoções de alguns de seus principais personagens.

Ao sair da prosa e ir para os versos, de igual modo, há uma riqueza considerável de exemplificações desta exploração dos detalhamentos do cotidiano. No entanto, apesar de haver muitas referências de desconstrução do mundo frente ao sujeito, é comum encontrar autores que caminham mais ao lado das proposições de Heidegger (2008; 2013) e outros pensadores da fenomenologia não niilista, como o imagismo, autores do (neo)concretismo e versões contemporâneas do modernismo atestam esta tendência à busca pelos breves sons, pequenos objetos e efemeridades situacionais do indivíduo, novamente, trazendo apenas um exemplo nacional temos a vasta obra de Manoel de Barros como grande ode ao cotidiano e seu preenchimento do existir por meio das situações e ocasionalidades que nos perpassam. 


\section{CONSIDERAÇÕES FINAIS}

O que foi apresentado neste artigo possui ressonância em trabalhos que tratam de análises literárias, sejam poéticas ou prosaicas, especialmente aquelas que possuem como profundidade mais expressiva de suas exposições a extensão dos seres e estares ocasionais e situacionais. Também há o cotidiano em seus recortes escalares como contributos ao desenvolvimento de uma metodologia de análise da facticidade, seus objetos, situações e representações, modulando o devir da existência como abertura onto-ontológica e as epifanias de seus detalhes na grandeza das pequenas coisas.

Mais do que elaborar uma trilha de discussão sobre o indivíduo é preciso relacionar, em um esforço de transição escalar entre a totalidade fenomênica e as singularidades fáticas, o cotidiano e os movimentos meta-teóricos e discursivos que pautam os grandes sistemas de pensamento. Este empenho fará com que, em ambos os lados, haja tanto uma sinergia quanto uma colaboração de aperfeiçoamento das análises a respeito dos recortes estabelecidos em cada situação específica. Nas páginas que precederam esta conclusão houve escolhas temáticas e de estudos tendo, como fim a ser almejado, uma expansão das reflexões suscitadas ao longo dos argumentos dispostos e expostos por diferentes autores.

Por fim, espera-se, com as reflexões apresentadas no decorrer deste artigo, oferecer um fomento metodológico e analítico para os temas colocados ao debate, como a cotidianidade e a singularização de nossas representações mundanas em cada uma das mais ínfimas significações que engendramos, concreta e abstratamente, emocional e psicologicamente, intencional e inconscientemente, individual e coletivamente, fazendo do nosso mundo um devir fugaz, intangível e inigualável.

\section{REFERÊNCIAS}

ANDRADE, Manuel Correia. [Org.] Élisée Reclus. Coordenador Florestan Fernandes. São Paulo: Editora Ática, 1985.

ASTRADA, Carlos. El juego metafísico: para una filosofía de la finitud. Buenos Aires: Libreria El Ateneo Editorial, 1942.

BACHELARD, Gaston. A poética do espaço. Trad. Antonio de Pádua Danesi. 2 ed. São Paulo: Martins Pontes, 2008. 
BACHELARD, Gaston. A Terra e os Devaneios da Vontade. Trad. Maria E. de A. Prado Galvão. São Paulo: Martins Pontes, 2013.

BARCELLOS, Jorge Alberto Soares. Territórios do cotidiano: introdução a uma abordagem teórica contemporânea. In: MESQUITA, Zilá; BRANDÃO, Carlos Rodrigues (Orgs.). Territórios do cotidiano: uma introdução a novos olhares e experiências. Porto Alegre/Santa Cruz do Sul: Ed. UFRGS/Ed. UNISC, 1995. p. 40- 48.

BEAUVOIR, Simone. A mulher desiludida. Trad. Helena Silveira; Maryan A. Bom Barbosa. Rio de Janeiro: Nova Fronteira, 2014.

CORRÊA, Roberto Lobato. Sobre a Geografia Cultural. In: Instituto Histórico e Geográfico do Rio Grande do Sul, 2009. Disponível em: <http://ihgrgs.org.br/artigos/contibuicoes/Roberto\%20Lobato\%20Corr\%C3\%AAa\%20$\% 20$ Sobre\%20a\%20Geografia\%20Cultural.pdf> Acesso 19 dez.2017.

COUTINHO, Evaldo. O lugar de todos os lugares. São Paulo: Perspectiva, 1976.

DARDEL, Eric. O homem e a terra: natureza da realidade geográfica. (Trad.Werther Holzer). Perspectiva: São Paulo, 2011.

DERRIDA, Jacques. Gramatologia. Trad. Miriam Schnaiderman e Renato Janini Ribeiro. São Paulo: Perspectiva, 2017.

GABRIEL, Kelton. Epistemologia da geografia do cotidiano. III NEER cultura, espaço e representações: mundos em transformações, 2010, Porto Velho. Anais do III NEER. Porto Velho: Sk Editora Ltda, 2009. v. 3. p. 34-38.

GOMES, Paulo César da Costa. Geografia fin-de-siècle: o discurso sobre a ordem espacial do mundo e o fim das ilusões. In: CASTRO, Iná Elias de; CORRÊA, Roberto Lobato; GOMES, Paulo César (orgs.). Explorações geográficas: percursos no fim do século. Rio de Janeiro: Bertrand Brasil, 1997. p. 13-42.

HARTMANN, Nicolai. New ways of Ontology. Translate by Reinard. C Kuhn. Chicago: Henry Regnery Company, 1953.

HARTMANN, Nicolai. Ontology: Laying the Foundations. Translate by Keith R. Peterson. Walter de Gruyter GmbH, Berlin/Boston: CPI books GmbH, Leck, 2019.

HEIDEGGER, Martin. Ontologia: Hermenêutica da facticidade. Trad. Renato Kichner. Petrópolis/RJ: Vozes, 2013.

HEIDEGGER, Martin. Marcas do Caminho. Trad. Enio Paulo Giachini e Ernildo Stein. Petrópolis RJ: Vozes, 2008.

KOSIK, Karel. Dialética do Concreto. $3^{\mathrm{a}}$ Ed. Trad. Célia Neves e Alderico Toríbio. Rio de Janeiro: Editora Paz e Terra, 1976. 
MARCUSE, Herbert. Materialismo histórico e existência. Trad. Vamireh Chacon. $2^{\mathrm{a}}$ ed. Rio de Janeiro: Tempo Brasileiro, 1968.

MARINHO, Samarone Carvalho. Geografia e Literatura: esboço crítico-compreensivo a um campo de estudo em discussão. In: SUZUKI, Júlio César; LIMA, Angelita Pereira de; CHAVEIRO, Eguimar Felício. (Org.). Geografia, literatura e arte: epistemologia, crítica e interlocuções. 1ed.Porto Alegre: Imprensa Livre, 2016, v. 4. p. 274-332.

MERLEAU-PONTY, Maurice. O Visível e o Invisível. Trad. José Artur Gianotti; Armando Mora d'Oliveira. São Paulo: Perspectiva, 1971.

MOOSBURGER, Laura de Borba. A Origem da Obra de Arte. Tradução: Laura de Borba Moosburger. Dissertação de Mestrado em Filosofia pela Universidade Federal do Paraná. Curitiba: UFPR, 2007.

NEGRI, Antonio; HARDT, Michael. Multidão: Guerra e democracia na era do império. $1^{\mathrm{a}}$ ed. Rio de Janeiro: Record, 2005.

NIETZSCHE, Friedrich. Gaia Ciência. Trad. Paulo César de Souza. São Paulo: Companhia das Letras, 2012 [1882].

PAZ, Octávio. O arco e a lira. Rio de Janeiro: Nova Fronteira, 1982.

RECLUS, Elisée. Do sentimento da natureza nas sociedades modernas. Organização e tradução Plínio Augusto Coelho. São Paulo: Expressão \& Arte: Editora, 2010.

SARTRE, Jean-Paul. O existencialismo é um humanismo. Petrópolis: Vozes, 2010.

SARTRE, Jean-Paul. A transcendência do ego: esboço de uma descrição fenomenológica. Trad. João Batista Kreuch. Petrópolis: Vozes, 2016.

SILVEIRA, Maria Laura. O espaço geográfico: da perspectiva geométrica à perspectiva existencial. GEOUSP - Espaço e Tempo, São Paulo, nº 19, p. 81-91, 2006.

SUZUKI, Júlio César. O espaço da narrativa: uma leitura de "preciosidade". Revista do Departamento de Geografia (USP), v. 19, p. 55-68, 2006. Disponível em: <http://www.revistas.usp.br/rdg/article/view/47252 > Acesso: 10 jan.2018.

SUZUKI, Júlio César. Geografia e Literatura: abordagens e enfoques contemporâneos. Revista do Centro de Pesquisa e Formação, v. 5, p. 129-147, 2017. Disponível em: <https://www.sescsp.org.br/files/artigo/e5e7f714/f8ed/443d/b048/0b3a58e284cc.pdf> Acesso: 16 jan.2018.

THAO, Tran-Duc. Fenomenológia y Materialismo Dialético. Trad. Raúl Sciarretta. Buenos Aires: Editorial Lautaro, 1959. 
Gilvan Charles Cerqueira de Araújo Geografia, Literatura e Arte, v.2, n.2, p. 173-200, jan./jun.2020 DOI: 10.11606/issn.2594-9632.geoliterart.2020.154781

Recebido em 20/02/2019.

Aceito em 14/09/2020.

Publicado em 07/11/2020. 